\title{
Cosmogonias e a música: Reflexão acerca do inconsciente coletivo e as representações musicais nos mitos de origem
}

\begin{abstract}
Anderson Carmo de Carvalho
Doutorando em música no PPGM - UNIRIO. Mestre em Educação Musical pelo PPGM da EM-UFRJ. Possui graduação em "Licenciatura em Música" pela Universidade Federal do Rio de Janeiro e Pedagogia "Licenciatura plena em formação de professores para Educação Infantil e anos iniciais do Ensino Fundamental para crianças, jovens e adultos e Bacharelado em Pedagogia nas Instituiç̃os e Movimentos Sociais" pela Universidade do Estado do Rio de Janeiro .
\end{abstract}

\section{Celso Garcia de Araújo Ramalho}

Doutor e Mestre em Poética (Ciência da Literatura) pela Faculdade de Letras da UFRJ. Bacharel em Música: habilitação em violão (UFRJ) com bolsa FUJB e Licenciado em Educação Artística com habilitação em Música (CBM-CEU. 
CARVALHO, A. C. de; RAMALHO, C. G. de A. Cosmogonias e a música: Reflexão acerca do inconsciente coletivo e as representações musicais nos mitos de origem. R. Científica UBM - Barra Mansa (RJ), ano XXIX, v. 21, n. 41, 2. Sem. 2019. p. 61-88.

ISSN 1516-4071

\section{Resumo}

O presente artigo tem por fim colaborar com a reflexão do lugar da música na origem humana. É um estudo exploratório que tem por objetivo demonstrar a frequente presença da música em mitos e cosmogonias, com isso, procura constituir um caminho produtivo para conjecturar a condição ontológica da música junto ao homem, tendo em vista que essa repetição entre criação e música pode alçar a hipótese de um inconsciente coletivo. Adota o procedimento metodológico de pesquisa bibliográfica e utiliza o referencial teórico calcado nos conceitos de Platão sobre a música e de inconsciente coletivo de Jung. Este estudo é parte de nossa pesquisa que também tem por fim inserir a reflexão do tema nas salas de aula em que se estudam, pensam e fazem música, impulsionando a exclusão de um discurso utilitarista e subserviente da educação musical unicamente como recurso didático ou de lazer. Ponderamos observar a música como conhecimento fundamental na formação humana. Para tanto, colhemos mitologias de origens de diversas civilizações em livros e periódicos. Nosso levantamento conclui que a música se apresenta nos mais diversos mitos cosmogônicos, em diferentes partes do globo, assim como em tempos distintos. Não só no lugar de criadora, mas também de criatura. Ela é gestante da existência na diversidade da experiência humana. É possível ponderar a existência de um inconsciente coletivo que rege esse tema como um arquétipo humano.

Palavras-chave: música; mito; etnomusicologia; inconsciente coletivo; arquétipo.

\section{Abstract}

The purpose of this article is to contribute to the reflection of the place of music in human origin. It is an exploratory study whose objective is to demonstrate the frequent presence of music in myths and cosmogonies, with this it seeks to constitute a productive way to conjecture the ontological condition of music with man, since this repetition between creation and music can increase the hypothesis of a collective unconscious. It adopts the methodological procedure of bibliographical research and uses the theoretical referential based on the concepts of Plato on the music and collective unconscious of Jung. This study is part of our research that also aims to insert the reflection of the theme in classrooms where they study, think and make music, impelling the exclusion of a utilitarian and subservient discourse of musical education solely as a didactic or leisure resource. We consider music as fundamental knowledge in human formation. To do so we collect mythologies of origins of diverse civilizations in books and periodicals. Our survey concludes that music presents itself in the most diverse cosmogonic myths, in different parts of the globe, as well as in different times. Not only in the place of creator, but also of creature. It is pregnant with existence in the diversity of human experience. It is possible to ponder the existence of a collective unconscious that governs this theme as a human archetype. 
Keywords: music; myth; ethnomusicology; collective unconscious; archetype.

\section{Introdução}

Presente em todas sociedades conhecidas que habitaram o orbe terrestre, a música ainda parece necessitar de apoio para localizar e fundar seu espaço na existência e na formação humana. O que é a música no homem? Quais forças biológicas e cognitivas moldaram o comportamento musical da humanidade e a diversidade musical? Qual a papel da música e por que toda cultura humana a possui? Quais são as características universais da música e do comportamento musical nas culturas? Essas perguntas podem ser variavelmente respondidas pelo senso comum: música é bom porque acalma, música é bom para matemática, música é bom para concentração, música é bom para disciplina e etc. Possivelmente, a dificuldade de responder questões desse tipo, em nosso questionamento, está na inabilidade da epistemologia ocidental positivista tratar de um conteúdo que não contempla a reprodutibilidade de dados como assim espera a ciência exata. Música, em suas múltiplas formas e manifestações, carece de ser igual e significar por igual para todos, em todos, e como resultado, seu estudo e caracteres na academia foram por muito deixados à margem.

O fenômeno da unidade música, conhecimento ininterrupto na ação humana, a ciência atual ainda não conseguiu cientificá-la pela razão. A não conversão da música numa ciência matemática como materialização de razões apofânticas, demonstrativas dentro dos critérios ajuizantes da ciência pura, aponta o que é música para uma intangibilidade, para um lugar simbólico, expressivo em que nem a semiótica conseguiu identificar, medir ou regular, mas simplesmente codificar e representar colocando-a sob controle dos signos do círculo acadêmico.

Ao largo dessa discussão, nosso olhar fundamenta-se no pressuposto de que a música é um espelhamento do humano e do verbo em ação da coisificação do ser. Quando discorremos sobre música, não tratamos da música de hoje ou a que a ciência positivista tentou matematizar, também não discorremos acerca da música como produto, mas sim da música como conhecimento, como um universal humano: como 
gênese. Música sendo o que faz o humano ser a si mesmo. Ao nosso modo, o homem é feito música ao passo que a compõe na medida de sua interação com o mundo que o cerca: a música é a própria vida. É a palavra cantada.

Então, neste artigo, atentamos nosso olhar para os mitos e cosmogonias de diversas civilizações, creditando fomentar nossa hipótese de que o homem é música sempre, sendo assim, representa de forma absoluta sua existência e sua gênese através dela não de forma ocasional, mas sim em um inconsciente intencional, como um inconsciente coletivo.

Para tanto, recolhemos em bibliografias variadas alguns mitos de antigas civilizações que alocam a música como criatura e criadora, como o audível e o inaudível, entre o som e a poesia, a fim de pensar como se caracteriza a presença da música no inconsciente humano. Isso, tratando como base o seguinte pressuposto. O homem é música enquanto homem ele é.

\section{Fundamentação Teórica}

\section{Música e homem}

Remontando os espaços da música, versamos que o mito nos é fundamental perspectiva para ver uma outra música, a música que há na música, o Ser que há em ser e se personifica em musicalidade e harmonia, isto é, na composição dos opostos complementares. A música é tão existente quanto o próprio humano é. Se a presença da música é codependente da existência humana, não nos parece possível em tratar do humano sem tratar de música.

Barbeitas (2007), citando Francesco Giannattasio remonta:

A “revolução antropológica" que caracterizou o último século, consentindo às diversas culturas um desvelamento recíproco, permitiu, entre outras coisas, constatar que não existem sociedades, por mais restritas e isoladas que possam ser, desprovidas de alguma forma expressiva musical. Em outros termos, é hoje possível compreender que a música constitui um "universal" do comportamento humano, como a linguagem ou a organização social (GIANNATTASIO, 1998 apud BARBEITAS, 2007 p. 1). 
Ao que parece, o homem só é homem enquanto sua musicalidade. A música sempre esteve no ato de existir humano e esse é o primeiro passo fundamental para nossa reflexão. Será então possível objetivar desse ponto de pensamento a música como um elemento em conjunto com o existir humano?

Uma diversidade de pensadores interrogou e desejou encontrar caminhos para responder essa incógnita: homem/música. Entre alguns: Na psicologia, Stumpf (2012) publicou em alemão, no ano de 1911, seu livro “The origins of music". Na filosofia podemos citar diversos autores que pensaram a música, desses ressaltamos Rosseau (2008) igualando a origem da música e das línguas, Schopenhauer (2001) que definiu a música como vontade e Nietzsche (1992), em seu livro “que alocou a música em alto patamar entre as artes. Em estudos da neurociência, Levitin (2007 e 2010) e Zatore \& Peretz (2006) contribuíram para observar a ação física do cérebro. $\mathrm{Na}$ musicologia, Blacking (1974) perguntou-se o quão musical é o homem e ampliou no seu trabalho de 1992. Sloboda (1985) também buscou responder essa questão. Além desses, o livro "The origins of music" organizado por Wallin, Merker \& Brown (2000) reuniu musicólogos, biólogos, antropólogos, arqueólogos, psicólogos, neurocientistas, etologistas e linguistas para examinar o que chamaram do nascimento da biomusicologia evolutiva. Além desses, o psicólogo inglês David Tame (1984) e o jornalista alemão Joachim Berendt (1993) apontaram para ciência oriental, defendendo a hipótese de que a música que se ouve é apenas um rascunho de uma música universal. Todos esses trabalhos remontam olhar para da música através da gênese humana, para tanto desejamos olhar para essas mesmas questões, observando os mitos em que a música se apresenta como principal. Três importantes princípios nos são basilares neste artigo.

Primeiro, a metafísica da harmonia apresentada a Glauco por Sócrates no diálogo (VII, 531a) da obra "A República” de Platão. Segundo Tomás (2005), o diálogo propõe a interpretação de dois tipos de música: a primeira possível de audição material e a segunda não, sendo esta segunda objeto de atenção, pois ao ser abstraída de sua sonoridade, ela atinge o mais alto grau, sendo a mesma pensada de forma independente da música tangível aos órgãos auditivos. Ela não estabelece contato com o mundo físico. Assim, para Sócrates há uma metafísica da música, pois a harmonia da música é um substrato da essência do universo (cosmos), como se houvesse um fluido universal de 
onde tudo provém. A música é a representação do alcance dos sentidos mais elevados e imponentes dessa essência universal. Para Sócrates todas as ações e pensamentos humanos tem necessidade de ritmo e harmonia (TOMÁS, 2005). Logo então, nosso trabalho se baseia em dois pensamentos socráticos sobre o que é a música. A que soa, é criatura e se apresenta em som: é audível. E a que permite soar: criadora e inaudível e provém do universo.

Em segundo, é nosso ponto de partida entender a palavra como palavra cantada. O elemento música aqui refere-se ao que soa, ao que é enunciado. Diria Rousseau: "a cadência e os sons nascem com as sílabas: a paixão faz falar todos os órgãos e confere voz a todo o seu brilho; assim, os versos, os cantos, a palavra, têm uma origem em comum" (ROUSSEAU, 2008, p.145). Para esse artigo, assumimos que todas essas atividades humanas são músicas enquanto essência, possuem musicalidade enquanto ritmo e movimento que possuem. Portanto, o mundo é som e silêncio e nossa perspectiva se constitui na medida em que todo o mito é sonoro, mesmo que não apresente um elemento acústico, pois que é enunciação da criação e representação da ação humana. Neste trabalho, reunimos mitos que apresentam o sonoro, observando a reprodutibilidade dessa face humana: sendo o mito, uma verdade.

Em terceiro, nossa hipótese principal de que a gênese humana se dá pela música, não é inaugural e nem isolada. Observamos isso em outros diversos autores, inclusive no educador musical Murray Schafer (2019). Ao inaugurar seu trabalho: "Vozes da tirania: templos de silêncio", em seu primeiro capítulo, o autor apresenta Ursound, o primeiro som, a força criativa original. Esta se apresenta nos mitos cosmogônicos. O autor observa que somente após o elemento acústico, o elemento visual entra em jogo nos mitos, porém esse lugar do som foi renegado pelo tempo.

...estaríamos errados ao pensar que o som, tendo funcionado tão criativamente na abertura do mito, fosse tão rapidamente relegado a uma posição secundária. De fato, ele continua sendo o meio pelo qual Deus e o homem se comunicam e, assim, mantém a posição de importância primordial ao longo da Bíblia (SCHAFER 2019, p18). 
Por fim, sabe-se que o mito para as sociedades primeiras é o sagrado, verdade, já que sempre se refere a uma realidade. Ao tratar da relação do mito e o pensamento dos eruditos do século XIX, o mitólogo Mircea Eliade pondera que:

Ao invés de tratar, como seus predecessores, o mito na acepção usual do termo, como "fábula", "invenção", "ficção", eles o aceitaram tal qual era compreendido pelas sociedades arcaicas, onde o mito designa, ao contrário, uma "história verdadeira" e, ademais, extremamente preciosa por seu caráter sagrado, exemplar e significativo. Mas esse novo valor semântico conferido ao vocábulo "mito" torna o seu emprego na linguagem um tanto equívoco. De fato, a palavra é hoje empregada tanto no sentido de "ficção" ou "ilusão" como no sentido familiar sobretudo aos etnólogos, sociólogos e historiadores de religiões - de "tradição sagrada, revelação primordial, modelo exemplar (ELIADE, 2000, p. 7).

O mito, nos dias atuais, não está em local secundário nas formulações acadêmicas sobre o homem, suas relações interpessoais e seus conhecimentos sobre si. Há verdade no mito, apesar da sua aparente premissa fantasiosa e suas alegorias ainda não tangíveis pela epistemologia vigente, ele revela como o homem pensa e sente. Para tanto, refletimos acerca de alguns mitos sonoros e seu lugar na reflexão sobre a música na formação do homem moderno através do modelo de inconsciente coletivo junguiano.

\section{A música como arquétipo do inconsciente coletivo de Jung}

Dois conceitos são necessários para compreender os rumos da experiência humana e a nossa intenção neste trabalho. Além disso, é preciso experienciar o mundo entendendo o modelo cíclico que as relações humanas estabelecem com o tempo mitológico, a memória e a música como conhecimentos originários. Não importa que instrumentos o homem empregue; em um determinado momento há de chegar a um limite de evidências e de convicções que o conhecimento consciente não pode transpor (JUNG, 2016). 
O primeiro conceito é o do inconsciente coletivo. Esse pode ser entendido como uma camada profunda da psique humana onde reside materiais herdados e se apresentam comuns a todos os humanos. Uma estrutura psíquica que acumula, durante a evolução e o ensaio humano, experiências que são reveladas na forma do que ele chamou de arquétipos. A teoria foi resposta de experiências com sua paciente Frank Miller, "Jung reuniu uma série de mitos, contos de fadas e motivos religiosos afins, oriundos de remotas paragens do mundo, para interpretar imagens dos pacientes. Ficou impressionado com os surpreendentes paralelos" (STEIN, 2006, p. 86-87).

Jung percebeu marcas padrões de comportamento, repetição dos modelos de interação com as coisas e as pessoas mesmo sendo estes de diferentes culturas e lugares geográficos distantes. Todo humano possui individualidade, suas roupas, suas comidas, sua língua, suas canções, sua memória, sua cultura: sua unidade. Entretanto, há marcas que são universais, não importa a região ou individualidade. Essas são algumas vezes relatadas através dos mitos e histórias, descrições imagéticas contadas durante os tempos e como forma de marcar esses padrões estabelecidos no homem, ele propõe uma ligação com as mitologias e histórias contadas através dos tempos, fazendo do mito algo real e instrumento central para psicologia junguiana na teoria dos arquétipos.

Jung aponta que o termo archetypus (arquétipo) se apresenta em outras literaturas, são elas: Filo Judeu com referência à imago dei no homem. Em Irineu no Adversus omnes haereses, no Corpus Hermeticum, em Dionísio Areopagia e em Agostinho, apesar dele não utilizar essa expressão, a ideia está estabelecida na sua literatura em "De divinis mominibus". Também se apresenta como perífrase explicativa do eros para designar as ideias como modelos de todas as coisas existentes. E em LevyBruhl para designar as figuras simbólicas da cosmovisão primitiva como representação do inconsciente (JUNG, 2014). Observa-se assim que essa ideia de conteúdos psíquicos coletivos anímicos não é de propriedade única desse autor, mas toma força na psicologia junguiana discernindo a forma de pensamento arcaico-mitológico graças ao advento do “inconsciente", bastante preconizado no seu tempo.

Não é o mundo como tal o conhecemos que fala a partir do seu inconsciente, mas o mundo conhecido da psique, do qual sabemos que reflete apenas em parte nosso mundo empírico, e que, por outro lado, molda este último de acordo com o pressuposto psíquico. $\mathrm{O}$ arquétipo 
não provém de fatos físicos, mas descreve como a alma vivencia a realidade física. A mentalidade primitiva não inventa mitos, mas os vivencia. Os mitos são revelações originárias da alma pré-consciente, pronunciamentos involuntários acerca do acontecimento anímico inconsciente e nada menos do que alegorias de processos físicos (JUNG, 2000 p.155).

Esse é o fundamento de nossa interlocução entre música, mitos e os arquétipos: uma marca que personifica o sujeito. Nossa hipótese apresenta a música como um fundamental humano, para tanto observamos os mitos.

Próximo as nossas linhas de pensamento acerca da gênese sonora que o ser passa durante sua criação e interação com o mundo físico e metafísico, Benenzon (1988) também nos é pertinente, pois assevera as relações extra e intercorpóreas com a música. Ao tratar dos conceitos de ISO compara as relações dinâmicas pessoais que o ser tem com os sons. Descreve que:

Esse conjunto de sons de movimento-som condensa os arquétipos sonoros herdados onto e filogeneticamente. Evolutivamente se lhe agregam as vivências sonoro-vibratórias e de movimento durante a vida intra-uterina, no período gestacional. Mais tarde se enriquece com as experiências vividas durante o parto, nascimento e durante todo o tempo de vida (BENENZON, 1988 p.34).

Para Benezon há um conjunto sonoro que é arquetípico para todo humano enquanto marca (som da chuva, do vento, objetos caindo, a voz feminina e masculina, os sons de instrumentos) e há os sons que são pessoais, da sua própria história, da unidade do ser humano. Esses são utilizados como medicamentos para tratamentos de pacientes em diversas situações. A ação da musicoterapia pretende respeitar essa identidade tanto para os sons que são aceitáveis como também os recusados. Para o musicoterapeutas os ISOs servem como elementos de anamnese. Isso reafirma nossos pontos acima assinalados acerca dos contatos sonoros primeiros e nossa hipótese da música como arquétipo. 
Por esses caminhos levantamos a hipótese de que a música é mais um dos diversos arquétipos, mais uma marca inaugural primordial que não foge do conhecimento inatista das relações padrões analisadas por Carl Jung. Quando se olha assim para a música, não é a música do ouvido, mas o Ser da música, a poiésis, a que apresenta o que estava velado e através da música: desvela. A que expõe o Ser, a manifestação da verdade do Ser, quando então encoberto, torna-se clareado. O belo e a beleza como formas em que essa verdade vigora. A arte como um por se obra da verdade (HEIDEGGER, 2010). É dessa música que tratamos e defendemos enquanto arquétipo inerente, inato e coletivo. Para nós a música é também uma entre essas diversas marcas universais onde se observa identidades e funções idênticas em diversas civilizações temporais e atemporais.

\section{Mitos cosmogônicos: a música como criadora e criatura}

Nossa busca foi realizada por levantamento bibliográfico sobre mitos e música. Essa apresentou alguns significativos pontos que aqui devem ser elucidados antes de apresentarmos a coleta. Nem todos os mitos de origem, ou histórias mitológicas que colhemos apresentaram necessariamente um elemento sonoro em primeiro nível, porém sabe-se que a escrita é posterior há muitas origens sociais e a tradição oral se perdeu no tempo, portanto algumas cosmogonias podem simplesmente não existir em registro para nós. No mesmo passo, algumas civilizações foram influenciadas pelas civilizações que as dominaram. Um forte exemplo disso, é a incursão da literatura judaico cristã em diversas regiões. E para tanto, algumas histórias podem ter sido influenciadas pela cultura dominante, fazendo com que a narrativa cosmogônica se torne próxima. Outro ponto fundamental é elucidar que muitos dessem contos eram poemas, cantados pela memória, foram passados por gerações através da memória rítmica musical.

Descobrimos que diversos mitos podem ser assertivos acerca da hipótese aqui proferida. Para Schneider (1986), a ideia da gênese do mundo como um som ou uma canção deve ser bastante antiga. Em seu estudo, defende que, quando nos mitos há a enunciação da gênese do mundo de forma assertiva, há sempre um elemento sonoro (acústico) que está presente de forma decisiva. No momento em que um deus manifesta 
a vontade de dar nascença a si mesmo, o homem, outro deus ou o céu e a terra emitem um som, o som da criação, expira, suspira, fala, canta, grita, ulula, vomita, troveja ou toca um instrumento. Por exemplo, num mito egípcio, a criação se dá com um crocodilo batendo na barriga com sua própria calda, fazendo uma menção a batida de um tambor. No mito esquimó, a caverna cantante, a goela escancarada. No mito Shruti hindus, a fenda na rocha dos Upanishads é responsável pelo som da criação. O som, vindo do vazio é obra do pensamento que faz vibrar o nada e, propagando-se, ele cria, é primeira força criadora, personificada pelos deuses cantores (SCHNEIDER, 1986).

Nos relatos da Criação de quase todas grandes religiões culturais, a Palavra aparece sempre unida ao mais alto Deus criador, quer se apresente como o instrumento utilizado por ele, quer diretamente como o fundamento primário de onde ele próprio, assim como toda a existência e toda ordem de existência provém. O pensamento e sua expressão verbal costumam ser aí concebidos como uma só coisa, pois o coração que pensa e a língua que fala se pertencem necessariamente (CASSIRER, 2013, p. 65).

Em outra exemplo:

Sempre que Deus se revelou aos seres humanos, Ele foi ouvido. Ele pode ter aparecido como luz. Todavia, para ser entendido, Sua voz se teve que ser ouvida. A expressão "E Deus disse", está em todas as escrituras sagradas. Os ouvidos são o meio de acesso do receptor (BERENDT, 1997, P.21)

Na Polinésia, Samoa, no Taiti e no Havaí, três deuses: Tane, Tu e Rongo criaram o mundo. O símbolo de Tune era a trompa, o de Tu a concha tríton e Rongo era a verdade contendo som e tonalidade (BERENDT, 1994)

$\mathrm{Na}$ história judaica, o homem é feito do barro e trazido à vida pelo sopro de Deus. E o próprio mundo é criado pela boca (sopro) dos deuses. Consta na Torá: "No princípio, Deus criou os céus e a terra. E a terra era vã e vazia, e (havia) escuridão sobre a face do abismo, e o espírito de misericórdia procedente de Deus soprava sobre a face 
das águas. Deus disse: "Haja luz, e houve luz" (TORÁ, 1962, pp. Gênesis 1 1-3). Posteriormente, na cultura judaico-cristã, o prólogo do Evangelho de São João: "No princípio era o Verbo. E o Verbo estava com Deus. [...] Tudo foi feito por Ele e sem Ele nada se fez [...] E o verbo se fez carne" (JOÃO 1, 1998).

Em hieróglifos, Thot, deus egípcio da palavra e da escrita, da dança e da música, da sabedoria e da magia, cria o mundo ao repetir sua palavra que ri” por sete vezes. Thot bateu palmas e soltou sete gargalhadas, nascendo os sete deuses (SERGL, 2017 apud ROLLAND-MANUEL, 1965, p.155). E, nos “Livro dos Mortos” egípcio, lê-se que o deus sol, Râ, é autocriador, e, quando então dá nome a si mesmo (essências e poderes), desse originário discurso, surge tudo quanto possui existência determinada e ser determinado: quando ele fala, surgem os deuses e os homens (CASSIRER, 2013); vocalizando os sons, ele materializava. Outra divindade egípcia, Khepri, o sol da manhã, gradualmente veio a ser considerado como uma encarnação do próprio Sol, e, por isso, tornou-se uma das formas do Deus do Sol. Cria-se ao proferir seu próprio nome.

Pode o som ser o criador como o que dá o prenome a deuses, como os deuses lituanos: deus do gado, Baudis, o rugidor, Birbullis, o zumbidor e o deus do terremoto, Drebkulis, o "agitador" (CASSIRER, 2013). O deus propaga seu nome, seu som e se cria, como o mito do Tibet, onde "Om Mani Padme hum” é um mantra, uma invocação ao Avalokitesvara. No princípio era o "OM". O Buddha da compaixão divina se dá quando evocado. Para os tibetanos, a criação também surgiu do vento. Com sua agitação, criou os gjatams, as formas primevas e o primeiro alicerce do mundo. $O$ vento soava enquanto o som formava a matéria e, em virtude do som destas, formavam-se outras formas (BERENDT, 1997).

Outro exemplo de como a música se apresenta nos mitos de origem é um mito Arecuná que trata da "origem do veneno de pesca": timbó. Num certo momento do mito, o arco-íris é uma serpente d'água que é morta pelos pássaros, cortada em pedaços e sua pele multicolorida é repartida entre os animais, conforme a coloração da parte repartida pelos animais, o animal ganhava o som de seu grito, sua cor e seu pelo ou plumagem. A morte da serpente no mito é objeto da criação de cores e sons particulares de cada animal que ali se desvela, formando a arara, o papagaio, o jacu, o rouxinol, o tapir, a capivara, o veado, a cutia, o caititu, o macaco. (WISNIK, 1989, p. 36). 
Sergl (2017) ${ }^{1}$ publicou em seu artigo uma série de mitos nos quais o sonoro é primeiro. Em sua pesquisa relata que, entre os nômades mongóis, índios Cheyenes americanos, os Zulus, os Massai e os Ewe africanos, os polinésios, os chineses e os Mbowamb da Nova Guiné, o trovão é elemento de identidade no momento da criação. Após o trovão é que o canto da luz do sol começa a radiar. Em outros exemplos, Mulungu, é o Deus criador dos Kamba e se dá como uma flauta. Para os Zulus, é também uma flauta de bambu objeto da criação. No Cáucaso, a terra foi separada do mar pelo sopro de dois tubos. Em Java, o som de um sino e na Índia, uma orquestra de tambores. Os aborígenes californianos acreditam que uma pena surgiu flutuando no ar e, girando, criou os sons que fizeram aparecer a Terra. Para os californianos, um grande ronco foi motivador da criação. Assim como para os japoneses, em outro mito da criação, um caniço sagrado fez surgir o criador. Já em mitos cosmogônicos como um ovo, Sergl notou que o rachar do ovo se faz como uma boca. Amon, deus egípcio, sob a forma de gansa, choca o ovo solar cuja boca emite o nascimento da luz, do sol. $\mathrm{Na}$ Índia, o ovo chocado possibilitou a saída do Deus - cantor, proferindo a primeira palavra (SERGL, 2017).

Na cosmogonia Yorubá, diz: Olurun existia e nada mais. E tudo que existia era uma massa infinita, ao mover-se lentamente e ao respirar, Olorun deu origem a água, ao soprar deu origem a Orun (céu), e dessa dança dos ventos criou terra, ar e água, posteriormente criando uma massa avermelhada (lama): Exu (SOARES, 2016).

Em outro mito japonês da criação, Amaterasu, a deusa do sol, refugiou-se em uma caverna fazendo com que o caos se desse, tudo tornou-se escuridão, pois ela era a luz do sol. Os campos de arroz não prosperaram e não se sabia mais o que era dia ou noite. Então, a pedido, Omoikane, deus da inteligência, Izanagi criou uma harpa com arcos e compôs suaves melodias que encantaram a ninfa Ameno Uzume fazendo com que esta dançasse e cantasse de forma provocante, exibindo suas partes íntimas com caretas irresistíveis. Amaterasu, a deusa que se pôs na caverna criando o caos, ouviu a

\footnotetext{
${ }^{1}$ Para tanto o autor se baseou em uma série de livros, dentre eles a coleção de 3 livros chamada: Homem, mito e magia de Arnaldo Gonçalves, editora Três de 1970. Também nos escritos de "A música: das origens à actualidade" de Fernando Lopes Graça. Enciclopédia da Plêiade, editora Portuguesa. Barcelos: Arcádia. 1965.
} 
canção e a risada de outros deuses ao longe, decidiu sair da caverna para ver. Nesse momento, o mundo iluminou-se (LUCAS, 2012).

Na história do México, para os astecas, "Inaudível e Imóvel" (o criador). Mudo como pedra: um iceberg. Um dia arremessou a montanha para longe de si e rompeu o silêncio por não conter o desejo de criar o mundo e os seres. Cantou: faça-se o mundo! E fez-se o mundo (BERENDT, 1997).

Freud (2008) observa outros mitos. No mito maia Popul Vuh, os deuses estão sentados em círculo de luz, nada mais existe, exceto um mar tranquilo e um céu sem sol. Solitários, após um colóquio, eles ordenam “Terra!", então brota das espumosas ondas a terra. Posteriormente, ordenam florestas, animais e outros por simples palavras. Os uitotos colombianos contam: "No começo, a palavra deu origem ao pai". Os índios maidus da América do Norte dizem que no início havia apenas água, e o Coiote gritou: "Que a espuma das ondas seja areia", e assim tudo se criou. O deus Nichant dos índios Gros Ventre (barriga grande), da região de Montana nos EUA, modelou um círculo de barro, pisou dentro dele, fechou os olhos e exigiu: "Que haja terra até onde meus olhos possam ver!". No Taiti, Ta'aroa concede extensão ao mundo por seu mero pronunciamento. $\mathrm{Na}$ antiga suméria, Gilgamesh separou céu e terra ao pronunciar o nome do homem (FREUD, 2008). Próximo a esses relatos, o filósofo Próclus, no século $\mathrm{V}$ a.C., descreve um poeta órfico que atribuía o nascimento dos deuses ao riso da divindade soberana e que o nascimento do homem se deu por suas lágrimas (MINOIS, 2003).

$\mathrm{Na}$ antiga Pérsia:

Hafiz um dos grandes poetas da antiga Pérsia conta seguinte lenda: "Deus fez uma estátua de barro à sua própria imagem e que essa estátua possuísse uma alma. Mas a alma recusou-se a ser aprisionada pois é de sua natureza ser livre e voar à vontade. A alma não quer estar presa, nem admite que se lhe imponham limites. O corpo é uma prisão e a alma recusou ser adentrá-lo então. Então Deus pediu aos anjos que tocassem sua música. E, à medida que os anjos tocavam, a alma ficou extasiada. Para poder sentir melhor a música e ouvir lá de perto a alma entrou no corpo". Hafiz diz: "As pessoas dizem que ao ouvir aquele 
som, a alma entrou no corpo; a verdade, porém é que a própria alma era o som" (BERENDT, 1997 p.215).

Também no livro francês de Felix Guirand (1935), há uma diversidade de mitologias que podemos enunciar. Na Mitologia Assírio Babilonica a água é elemento essencial. A fusão da água fresca (Apsou) e de água salgada (Tiamat) deu origens aos deuses e todos os seres humanos. Apsou é o pai e Tiamat, personificação do mar, é o feminino que dá à luz ao mundo. Das suas águas combinadas saiu primeiro Mummu (o som das ondas), então um par de serpentes monstruosas, Lahmou e Lahamou deram à luz a grandes deuses Anshar e Kishar.

Na mitologia Eslava, o nascimento dos deuses, o dualismo primitivo: Bielobog e Tchernobog ("um Deus branco" e "Deus negro"). Em seu panteão de deuses há o importante Deus Perun, o Deus trovão e também da fertilidade. Segundo Guirand, na mitologia céltica há uma ausência de mito de origem. No País de Gales foi comunicado apenas relatos do início e nunca escrito. Posteriormente, estes ensinamentos foram escritos nos "Barddas". Diz assim: No começo não havia nada, só Deus e Annwn. A vida organizada começou pela Palavra - Deus pronunciou Seu nome inefável e "Manredo"foi formado. O Manred era a substância primordial do universo. A cosmogonia babilônica é uma das mais conhecidas do mundo. A figura do Caos novamente é vista em oposição aos deuses. Uma grande batalha entre essas duas forças teria dado origem ao universo, em um sonoro conflito cósmico entre a Ordem e o Caos. A deusa Tiamate, que representava o oceano primitivo, batalha contra Marduque e é derrotada. Os céus e a terra são criados a partir da carcaça dividida de Tiamate. Com o sangue daqueles que conspiravam com ela, a humanidade é criada. $\mathrm{Na}$ mitologia filandesa, Lönnrot reuniu canções da antiga Finlândia e escreveu o Kalevala em 1828. Nele, o autor relata a existência de um personagem central de muitas histórias e também da cosmogonia: Väinämöinen, deus dos cânticos, músicas e poesia. No início, eram apenas as águas primordiais e o Céu. Mas o Céu também tinha uma filha, chamada Ilmatar. É Ilmatar quem criou o mundo em um dia e deu à luz Väinämöinen, o primeiro homem, cujo pai era o oceano. Com canto mágicos, Väinämöinen vence batalhas. A 
primeira menção de Väinämöinen na literatura é escrita por Mikael Agricola em 1551. (GUIRAND, 1935).

Os mitos guardam a força primordial de dizer e mostrar o tempo inicial das coisas: a origem e o que é originário. A música palavra. $O$ tempo então não se faz divisor com relação ao valor dessas ações humanas que são importantes para as civilizações primárias e para as modernas. Toda cosmogonia é sonora, é o que permite soar e o que dá existência. O que há de existe surge do fundo acústico: da música, da palavra cantada.

\section{Mitologia Grega, Nórdica e a poesia cantada}

A música na Grécia não era um ente isolado, era um grupo de conhecimentos que se entrelaçava como uma teia onde: dança, composição musical, habilidade instrumental, matemática, ginástica e poesia encontravam-se conectados num todo orgânico (TOMÁS, 2005, p. 19). A mousiké fazia parte dos ritos gregos, da formação da Paideia e da tradição oral e mitológica que se estabeleceu por muitos séculos na Grécia através dos poetas e seus aedos. Por ser memória, era ela um conhecimento do fazer conhecer a origem que reunia o que hoje fragmentamos em música, pensamento, filosofia e literatura.

O poeta carregava consigo a cosmogonia, quando da permissão das musas ele cantava a origem. Por que cantavam em forma de poema? Utilizavam assim já que essa forma de contar as histórias facilitava na memorização. "Afinal um poema é mais memorizável do que um parágrafo em prosa; e uma canção, mais memorizável do que um poema” (TOMÁS, 2002, p. 46; HAVELOCK, 1996, p. 189). Assim se fazia a tradição oral na Grécia. "Como os próprios gregos diziam, a Memória foi mesmo a Mãe das Musas" (HAVELOCK, 1996, p. 140).

No mito das musas, conta-se que Zeus comanda sua facção de deuses do Olimpo numa batalha contra os Titãs, filhos de Urano. Estes perderão a batalha e serão presos ao final. O embate quase convulsiona a terra, o cosmo é abalado por uma exaustiva batalha e seus sons. Terremotos e tempestades são lançados. Zeus, por fim, é nomeado "o rei". Foi solicitado a Zeus que se criassem divindades capazes de cantar a vitória e perpetuar a glória dos Olímpicos. Zeus, então, partilha o leito com Mnemósine, a deusa da memória, filha de Urano (céu) e Gaia (terra). Ela sabe tudo, 
ontem, hoje e sempre; Mnemósine é onisciente. Ela é a personagem mítica que Zeus escolhe para registrar a vitória depois de árdua e importante batalha para ser o Rei dos Deuses. Haverá ela de ser responsável de celebrar a vitória através dos séculos. Imortalizar-se-ão seus feitos teogônicos: eis que estão no agora e sempre. Os dois deuses se relacionaram durante dez noites consecutivas, e, um ano depois, Mnemósine deu à luz nove filhas em um lugar próximo ao monte Olimpo. As nove musas, responsáveis por guardar a cosmogonia, cantavam o presente, o passado e o futuro e, sempre que evocadas, são partícipes. Nos primórdios, eram apenas deusas da música, formando um maravilhoso coro feminino. O poeta, portanto, tem na palavra cantada o poder de ultrapassar e superar todos os bloqueios e distâncias espaciais e temporais, um poder que só lhe é conferido pela Memória (Mnemosyne) através das palavras cantadas (Musas) (TORRANO, 1995; HAVELOCK, 1996; ANDRÉS, 2012).

Eliade (2000) completa:

A deusa Mnemósine, personificação da "Memória" irmã de Cronos e de Oceanos, é a mãe das Musas. Ela é onisciente: segundo o Hesíodo, ela sabe "tudo que foi e tudo que será". Quando o poeta é possuído pelas Musas, ele sorve diretamente da ciência da Mnemósine, isto é, sobretudo do conhecimento das origens, dos primórdios, das genealogias. A musas cantam, com efeito, a começar do princípio o aparecimento do mundo. (...) Graças à memória primordial que ele é capaz de recuperar, o poeta inspirado pelas Musas tem acesso as realidades originais. Essas realidades manifestaram-se nos Tempos míticos de princípio e constituem o fundamento desse mundo (ELIADE, 2000, p. 108).

Outra cosmogonia que nos é significativa é a que nos apresenta o hidromel da poesia. Gaimam (2017) escreve que na mitologia nórdica, surgida na região da Alemanha e posteriormente espalhada pela península escandinava, e para os Vikings, (Ilhas Orcades, Escócia, Irlanda e o norte da Inglaterra, o deus Odin é o deus da criação do homem. Nessas histórias, também contadas através das Edda Poéticas, Odin é o mais poderoso e o mais velho dos deuses, um homem alto com manto e chapéu. O Odin tem dois corvos Hugin (pensamento) e Munin (memória). Assim como na mitologia grega, a memória é a possibilitadora do saber tudo; graças a ela, o ser torna-se poderoso. 
Hugin e Munin voam o mundo trazendo notícias, quando, então, sussurram dos ombros do deus o que há no mundo quando está sentado em seu trono em Hlidskjalf. Nada pode ser ocultado de Odin graças ao "pensamento" (Hugin) e à "memória” (Munin). É Odin, que, vencedor da batalha contra o gigante Ymir, soprou a vida para dentro de dois troncos mortos, depois foram vivos, duas pessoas nuas. Por isso, Odin é pai de todos, porque foi pai dos deuses e porque soprou a vida nos avós dos avós de nossos avós. $\mathrm{Na}$ mitologia nórdica, Kvásir é resultado do cuspe em uma tina quando da união dos Aesir e dos Vanir. A saliva misturada era o símbolo de um acordo selado. Foi então que Odin decidiu transformar essa mistura em um homem: criou-se Kvásir. Conhecedor dos poemas, os cânticos e os Kennings, era o mais sábio dos deuses pois combinava cabeça e coração e sabia todas as perguntas. É da morte de Ksávir (sangue dele com mel) que surge o hidromel da poesia. Este foi cuspido por Odin para os barris como se uma ave levasse para seus filhotes o alimento. Desde aqueles tempos, toda vez que alguém é capaz de fazer magia com as palavras (poesia e música), compor poemas e narrativas épicas, diz-se: provaram do hidromel da poesia, presente de Odin. Diz o poema épico que, pelo caminho, Odin expeliu hidromel pelo traseiro, jorrando-o fedorento. Ninguém até hoje quis bebê-lo e, quando poetas ruins, de sorrisos tolos, declamam rimas feias, diz-se que provavelmente beberam dele. Vê-se aqui que o hidromel da poesia é criado do ser que tudo sabe e tem todas as respostas, e, por ser tão importante, Odin vai em busca deste e o espalha pelo mundo (GAIMAM, 2017).

\section{Entre o Ocidente e o Oriente}

No mito hinduísta iogue, o universo brota da sílaba "OM"2, que é o imprescindível Brahma, é o universo. Não só o som do "OM" é representação da criação cósmica como, quando pronunciada, afina realmente o indivíduo pelo próprio Tom celestial é um som único e soberano, utilizados em técnicas de meditação, em que não se pronuncia, afinando a alma diretamente pelo Som sem Som (TAME, 1984). É a semente de onde toda criação se fez, todo o universo é uma projeção de sons. É uma

\footnotetext{
${ }^{2}$ Interessante observar que a palavra "mãe", escrita em diversas línguas de forma parecida, também possui a letra "M". O que cria, o que gera.
} 
vibração tão elevada que está além da compreensão humana. Para os iogues, do som primordial, fez-se música. O primeiro deus a receber a música foi a deusa do conhecimento, Shiva (ANDRÉS, 2012).

Os vedas descrevem o som do "OM" como um som inaugural na criação, vibração primeira, som cósmico, Logos, a música das esferas, o Verbo ou Tom único. Tudo que surge e nasce da natureza vibratória seja ela tangível ou uma energia, luz, calor ou o som audível, para eles manifestam o próprio som cósmico. A música, então, ocupa um lugar vital na mitologia hindu. Ela é o elo entre o homem e a criação, capaz de moldar e alterar os efeitos físicos que se estabelecem no mundo.

A noção de que o poder da música, especialmente a palavra entoada, pode influir no curso do destino humano e até na ordem do universo, remonta as mais antigas formas sobreviventes da música indiana, a saber, a dos vedas. A fórmula entoada é o fulcro de toda a complicada estrutura das oferendas e sacrifícios védicos. O poder das palavras enunciadas com a entoação correta determina a eficiência dos ritos: um engano pode destruir tudo. Proclamamos sacerdotes que, por sua atividade, não só sustentam a ordem da sociedade humana, mas também mantém a estabilidade do universo. Por intermédio de cerimônias bem dirigidas, eles detêm um poder compulsivo sobre os próprios Deuses. O instrumento que produz esse poder é a palavra (WELLESZ, 1957 apud TAME, 1984 p. 186-187).

Na mitologia hindu, Shiva, o amável, é um dos deuses da trimúrti, a trindade hinduísta. É o destruidor, que destrói para construir algo novo, o transformador. É o damaru de Shiva que marca o ritmo da sonoridade na criação do mundo, expressa o circular, os ciclos da luz e da sombra, da vida e da morte (ANDRÉS, 2012) Conta o mito que Shiva com o som do damaru marca o ritmo do universo e os compassos de suas danças dão movimento à vida que existe. Às vezes, ele deixa de tocar por um instante, para ajustar o som do tambor ou para achar um ritmo melhor e, então, todo o universo se desfaz e só reaparece quando a música recomeça (LEIROS, 2015). Ao nosso ver fazendo uma analogia aos grandes períodos apocalípticos dos tempos, como os períodos de mudança da humanidade, como um eterno ciclo vivo. Outro deus-criador védico, 
Prayapati, era hino e canção: os ritmos eram seus membros e os membros de deus criou o mundo (BERENDT, 1997).

Como prática religiosa e sendo uma das culturas mais antigas da história das sociedades, nos é conveniente perceber que seus apelos míticos são baseados no som, no musical, no poder da voz e da relevância da respiração. O próprio nome do deus Brama significa força mágica, palavra sagrada, hino, em que todas as ocorrências míticas e eventos divinos são declaradamente recitações cantadas. Como já dissemos a palavra "OM" tem poder de ressoar a gênese do mundo, o que quer que tenha existido no passado, o que quer que exista no agora, o que quer que venha a existir no futuro, é "OM". E o que quer que transcenda o passado, o presente e o futuro além de nosso entendimento também é "OM" (WISNIK, 1989, p. 38). Para os hindus a música era uma ciência primeira: saber primordial.

$\mathrm{Na}$ cosmogonia chinesa, há a "Origem Una" é criadora de todos os tons cósmicos e de todos os sons da terra, todas as coisas. A vibração cósmica fundamental, não diferençada, era um conceito central. A música era o som audível, a emanação do Som Fundamental, inaudível. O Som Fundamental governa o mundo.

Foi essa vibração Una, que emanando de Deus, veio a ser os dois yang e yin - sobre os quais se baseou toda a criação. Acreditava-se que a vibração Una, origem de toda a matéria, energia e ser, era o Verbo enunciado do Supremo. Visto que cada um dos doze "Tons Cósmicos" não passava de um aspecto - uma duodécima - parte da Vibração Una, achavam os chineses que, literalmente, cada nota musical, reflexo de um dos doze tons, era também uma manifestação terrena do Grande Tom Uno. Cada nota de música, na verdade, executava-se como uma celebração, uma homenagem e evocação do Tom Pai. [...] eram muito reverenciados pelos sábios músicos (TAME, 1984, p. 43).

Os Guaranis também nos servem de exemplo de cosmogonia que apresenta o som como ente criador do cosmo. Segundo Jecupé (2001), a mitologia dos TupyGuarani, Nande Ru Tenondé (Nosso pai primeiro) simula a Suprema Consciência cujo corpo é espaço imanifestado e sua presença se desponta de forma a ser essência manifestada: o ritmo, o Espírito-Música ou Grande Som Primeiro, como geradora da 
vida (JECUPÉ, 2001). Para os Tupis, a música e o canto não somente são a matéria primeira, mas também são entendidos como bálsamo de cura, pois compreendem que a música conecta a alma do enfermo ao próprio espírito da vida, ao primeiro som produzido por Ñamandu.

O ser humano é percebido como "alma-palavra" é o que se expressa mediante a linguagem e por meio do pensamento. Ser e som têm o mesmo sentido. Para essa percepção é necessário ampliar o nosso conceito de som para além da vibração sonora, percebê-lo como corpo-vida, princípio dinâmico da luz cuja forma, denominamos “consciência” (JECUPÉ, 2001, p. 56).

Quando o espírito toma a vida ele se torna memória que ganha corpo na voz, no entoar, é entoado, passa a Ser, desvela da escuridão do não existir, reconhece-se enquanto ser e advém a possuir um tom, um som, um sopro criador. A vida é entoada como forma, corpo, palavra que possui uma essência, um espírito. O nome é espírito provido de alma, sendo soar-silêncio, silenciar sonoro, som-silente.

Segundo o trabalho de Jecupé (2001) sobre a mitologia tupi, o povo brasileiro mais ancestral que se tem notícia são os Tupy (Tu - som; py-pé, assento), tudo ressoa, todos objetos nascem com um som, tudo entoa segundo essa cosmogonia: pedras, animais, vento, terra, o homem, todos possuem uma manifestação sonora. Outros grupos indígenas do continente também apresentam cosmogonia e mitologia rica em sonoridades, tais como: os Ywalapití, Arecuná, Wauja e Kamayurá, trata-se de uma verdade que ultrapassa as barreiras geográficas brasileiras instituídas pelos colonizadores, uma verdade ameríndia.

Esses mitos remontam o alugar da música e do som como conhecimento originário na formação das sociedades, são memórias vivas e cíclicas de um eterno retorno da experiência humana na sua relação com a música, à memória e a existência. "Graças á memória primordial que ele (homem) é capaz de recuperar, o poeta inspirado pelas musas têm acesso às realidades originais" (ELIADE, 2000), pois para o estudante atento aos modelos humanos, a gênese desses conhecimentos não devem ser menosprezada já que "conhecer os mitos é aprender o segredo da origem das coisas. Em outros termos, aprende-se não só como as coisas vieram à existência, mas também onde encontrá-las e como fazer com que reapareçam quando desaparecem" (ELIADE, 2000, 
p. 18). Conhecendo a origem é possível estabelecer relação com o real, encontrar o que é do humano e seu conhecimento originário que é também encontrar-se.

Seria acaso encontrar tamanha comunhão entre mitos tão longínquos em tempo e espaço como os mitos Chinês e o Guarani? Mitos onde a música é criadora e criatura. Ao contrário pensamos, esses conhecimentos são representações arquetípicas. É reprodução da atitude humana desvelada em mitos.

A música é memória e origem nas circunstâncias do que é ser o mundo enquanto mundo ele é.

No fundo, o universo é essa harmonia e polifonia musical, que a tudo ordena e manifesta no que é enquanto sentido, mundo. É importante perceber que não é a memória que origina a unidade, mas é esta que por ser e para unidade, constitui a memória (CASTRO, 2011, p. 120).

Então, esse eterno vir-a-ser que é o pensar o homem e música não pode se distanciar dos mitos, eles dão apoio para aprofundar a importância da música para a alma humana em sua integralidade e complexidade, pois o mito é propriamente: verdade. Velar e desvelar da essência originária do humano.

\section{Mito, ciência e música}

Como último exemplo a ser elaborado para compreensão de nossa narrativa, sendo claro que essas narrativas não se enceram aqui, pertinente é refletir sobre o distanciamento do homem atual com as mitologias e os estudos levantados pelo astrônomo Duane Hamacher. O pesquisador vem aproximando a cosmogonia aborígene da Austrália com a ciência moderna através de estudos sobre meteoros e astronomia aborígene. Seus estudos estão conseguindo ligar o que denomina-se de fantasioso com a epistemologia da Ciência enquanto acontecimento real, isto é, racional. Em Hamacher (2013) o autor elabora como a cosmogonia aborígene tem relação com um meteoro caído, indicando a história de Arrernte sobre a criação de Tnorala, ou Gosse’s Bluff, uma cratera criada há 150 milhões de anos atrás. 
No tempo do "Sonhando" (o sonhar) um grupo de mulheres toma a forma de estrelas e dança na Via-Láctea. Uma das mulheres tinha um bebê em seus braços e ficou cansada, então colocou o bebê em uma cesta de madeira (turna). Enquanto as mulheres continuavam a dançar, mexendo com toda Via-Láctea o "Turna" virou e o bebê das estrelas caiu sobre a borda desse berço, mergulhando na Terra. $\mathrm{O}$ impacto forçou as rochas para cima formando as paredes de estrutura circular, criando assim a cratera hoje existente em Tnorola. E o primeiro homem e a primeira mulher foram criados. $\mathrm{O}$ mito finaliza proferindo que a mãe do bebê, a Estrela da noite e o pai, o Estrela da manhã, continuam até hoje procurando seu bebê. As crianças que não olharem para essas duas estrelas ficarão doentes, já que estas procuram seu bebê que caiu durante a dança. (HAMACHER; NORRIS, 2009, p. 15)

A ciência empírica que não considerava as cosmogonias como válidas agora se depara com Tnorola. A história da criação sobre uma perspectiva aborígene e a história da criação sobre a perspectiva científica se respondem, elas se encontram e estabelecem um novo paradigma. Hoje ainda a tradição exige uma saudação ao entrar na grande cratera que de acordo com os cientistas foi um meteoro que criou. Ao observar a chamada Corona Australis, pode-se perceber que realmente ela aparenta um berço virado (HAMACHER; NORRIS, 2009; HAMACHER; GOLDSMITH, 2013).

Entendemos que de alguma forma a dança dessas mulheres "no tempo do sonhar" presentifica música, enquanto origem, ou mesmo enquanto o próprio. Representa uma figuração ao olhar atento que intentamos apresentar ao pensar a música como membro permanente das cosmogonias espalhadas por várias civilizações, em tempo e lugares diferentes de povos de culturas diversas. A música então faz parte de um dos conhecimentos originários da humanidade, ela sempre esteve. Diria Heidegger, "O que há de mais antigo entre as coisas antigas nos seguem em nosso pensamento e, portanto, vem ao nosso encontro" (TOMÁS, 2002, p. 50). Olhar a memória não é olhar para trás, mas sim olhar para dentro.

\section{Considerações Finais}

Todo nascimento é digno de homenagem e comemoração, investidos de autoridade da força divina, os humanos sagram-se mortais e trazem à vida a autoria de 
memórias colhidas, dando conta do dimensionamento das esferas humana e divina, terrestre e celeste, na reunião do sagrado: um presságio - a prece-palavra que conduz à saga da vida. Quando denominamos a música como elemento que cria e que é criatura, olhamos para uma outra música, não só a que soa, mas a que permite soar: a música que há na música. Assumimos que nossa temática não é inaugural, porém necessária para então reflexão dos fazeres em música.

A música que é de experiência comum para todas as civilizações pode ser identificada como um desses símbolos universais inconscientes, uma experiência ou conhecimento que se estabelece para todos em todos como arché. Como tal, nos mitos, a música apresenta-se como criadora, criatura e partícipe, faz parte de um "inconsciente coletivo", um arquétipo, pois como já elucidamos neste trabalho, não existem sociedades, por mais restritas e isoladas que possam ser desprovidas de alguma forma expressiva musical. Entre as estruturas universais de padrões, que toda a mente humana pode reconhecer, estava ela desde o começo sendo experimentada e utilizada para a memória de tradições orais importantes e expondo a verdade do Ser.

Como observamos no mito hindu de Shiva, o mundo se cria a partir da repetição do seu damaru (tamor) e isso nos faz refletir acerca dos batimentos cardíacos humanos, que como um tambor em ostinato ininterrupto, quando cessado, expõe a continuação da existência. Também quando o mundo se cria, faz se som segundo os iogues, assim como um bebê grita sua existência nos seus primeiros segundos de vida. $\mathrm{O}$ mito então se torna real quando observado por esse ponto de vista, tudo tem ritmo, tudo tem vida, tudo tem um musicalidade, todo o humano é uma unidade: uma música na sua singulaidade. A obra humana quando obra está em perfeita ritmicidade com o homem e seu tempo, assim como a natureza não cessa seu fazer, o ritmo humano não cessa seu pertencimento no constante ato de criar com o universo que o cerca. Agir e ser sendo sempre um pouco mais do que se foi antes.

É preciso expandir formulações profícuas acerca da ascensão da música no currículo escolar além das justificativas epistemológicas que hora ouvimos como: música ser bom pra concentração, bom para acalmar, bom para formulações de sinapses, bom para matemática e etc. Não desvalidamos essas aplicações, porém acreditamos não serem medulares. $\mathrm{O}$ que nos fomenta pensar, música é a própria atividade humana: nela, um reflexo do que é a música. Não seria reprodutividade acadêmica os dados hora 
selecionados nesse trabalho? Não seria uma amostra de que há uma repetição de ações históricas não dependentes e similares? Vale-nos observar o homem como sujeito único, mas que possui identidade de humano, assim é a música no homem.

Parece-nos salutar impulsionar narrativas como essas para nossa reflexão possa alcançar novas formas de pensar o homem e o lugar da música no currículo formativo, localizando a música em seu devido espaço: na própria existência humana.

\section{Referências}

ANDRÉS, Ramón. Diccionario de música, mitologia, magia y religion. Barcelona, Acantilado, 2012, p 1773.

BARBEITAS, F. Música, linguagem, conhecimento e experiência. Terceira Margem: Revista do Programa de Pós-Graduação em ciências da literatura, Rio de Janeiro, v. 25, Ano XV, p. 267, jul.-dez. 2011.

BENENZON, R. Teoria da musicoterapia: contribuição ao conhecimento do contexto não-verbal. São Paulo: Summus. 1988. p, 187.

BERENDT, J. E. Nada Brahma: A música e o universo da consciência. São Paulo: Editora Cultrix, 1997. p. 288.

BLACKING, John. How musical is man. Seattle: The University of Washinton Press, 1974.

CASSIRER, E. Linguagem e mito. Tradução de J. Guinsburg e Miriam

Schanaiderman. 4a . ed. São Paulo: Perspectiva, 2013. 127 p. Título original: Sprache und mythos - Coleção Debates 50.

CASTRO, M. A. Musicalidade, o penhor de aprender a ensinar. Terceira Margem:

Revista do Programa de Pós-Graduação em ciências da literatura, Rio de Janeiro, v. 25, Ano. XV, p. 267, jul.- dez. 2011.

CASTRO, M. A. Poiesis, sujeito e metafísica. In: CASTRO, M. A. D. A construção poética do real. Rio de Janeiro: 7 Letras, 2004. p. 300. 
LUCAS, Fernando C. Mujeres en la historia del teatro japones: de Amaterasu a

Minako Seki. Castelolo de la Plana: Publicacions de la Universitat Jaume I, D.L. 2012 p. 205.

ELIADE, M. Mito e realidade. Tradução de Pola Civelli. 6º. ed. São Paulo:

Perspectiva, 2000. 179 p. Título original em Inglês: Myth and Reality - Coleção

Debates 52.

FREUND, P. Mitos da criação: As origens do universo nas religiões, na mitologia, na psicologia e na ciência. São Paulo: Cuntrix, 2008.

GAIMAM, N. Mitologia Nórdica. Tradução de Edmundo Barreiros. 1º. ed. Rio de Janeiro: Intrinsica, 2017. 288 p.

GUIRAND, F. Mythologie Générale. Paris. Editora Librairie Larousse, 1935. 448p.

HAMACHER, D. W. H.; NORRIS, R. P. The Astronomy of Aboriginal Australia. [S.1.]: [s.n.], 2009. Disponível em:

<http://www.atnf.csiro.au/people/rnorris/papers/n230.pdf $>$. Acesso em: 17 jun. 2017.

HAMACHER, D. W.; GOLDSMITH, J. Aboriginal oral traditions of Australian Impact Craters. Journal of Astronomical History and Heritage, p. 295-311, 3 jun. 2013. Disponível em: <https://arxiv.org/ftp/arxiv/papers/1306/1306.0278.pdf. > Acesso em: 06 out. 2016.

HAVELOCK, E. A. A revolução da escrita na Grécia: e suas consequências culturais. Tradução de Ordep José Serra. São Paulo: Editora UNESP, 1996. 370 p.

HEIDEGGER, M. A origem da obra de arte. Tradução de Idalina Azevedo e Antonio de Castro. São Paulo: Edições 70, 2010. 253 p. Título original: Der Ursprung des Kunstwerks.

JECUPÉ, K. W. Tupã Tenondé: a criação do universo, da terra e do homem segundo a tradição oral guarani. São Paulo: Peirópolis, 2001. 115 p. 
JOÃO 1, 1.-3. Evangelho Segundo São João. In: Bíblia de Jerusalém. Tradução de Joaquim de Arruda Zamith. São Paulo: Paulus, 1998. p. 2207.

JUNG, C. G. Os Arquétipos e o inconsciente coletivo. Tradução de Maria Luiza Appy e Dora Mariana R. Ferreira da Silva. 11ª ed. Petrópolis: Vozes, 2014. 456 p.

JUNG, C. G. O homem e seus símbolos. Tradução de Maria Lúcia Pinho. 3ª ed. Rio de Janeiro: Harper Collins Brasil, 2016. 447 p.

LEIROS, M. Música - A chave do universo. 1. ed. [S.1.]: Clube de Autores - EBOOK, 2015. 225 p.

LEVITIN, D. This is your brain on music: The science of a human obsession. New York: Plume, 2007.

LEVITIN, D. Why music moves us. Nature, n. 464, 2010. p. 834-835.

MINOIS, G. História do Riso e do escárnio. São Paulo: UNESP, 2003. 654 p.

Historie do rire et de la dérision.

NIETZSCHE, Friedrich. O Nascimento da Tragédia (tradução de J. Guinsburg); São Paulo: Companhia das Letras, 1992.

PLATÃO. Diálogos III - Socráticos: Fedro (ou do Belo); Eutífron (ou da Religiosidade); Apologia de Sócrates; Críton (ou do Dever); Fédon (ou da Alma). Tradução de Edson Bini. 2a ed. São Paulo: EDIPRO, 2015. 274 p.

A República de Platão. Tradução de J. Guinsburg. 2a . ed. São Paulo:

Perspectiva, 2016.

ROSSEAU, J. Ensaio sobre a origem das línguas. Tradução de Flavia M. L. Moretto. Campinas: Unicamp, 2008. 183 p.

SCHAFER, Murray. Vozes da tirania: Templos de silêncio. Tradução de Marisa Trench de Oliveira Fonterrada. São Paulo: Editora UNESP, 2019.

SERGL, M. J. A origem do universo e os mitos sonoros. Revista Observatório, Palmas, v. 3, p. 370-389, mai. 2017. Disponível em: <http://anais- 
comunicon2016.espm.br/GTs/GTPOS/GT7/GT07-MARCOS_SERGL.pdf> Acesso em: 12 jun. 2017.

SCHNEIDER, M. Le rôle de la musique dans la mythologie et les rites des civilisations non-européennes. In: MANUEL, R. Histoire de la musique. v. I. Paris: Gallimard, 1986. p. 131-214. Disponível em:

<https://archive.org/stream/histoiredelamusi027097mbp\#page/n149/mode/2up/search/ schneider>. Acesso em: 26 Março de 2018.

SCHOPENHUAER, A. O mundo como vontade e representação. Tradução Sá Correia. $1^{\circ}$ ed. Rio de Janeiro: Contraponto, 2001. 431 p.

SOARES, Marcio. O Elegun De Ogum. Joiville: Clube de Autores, 2016. 350 p. SLOBODA, J. The Musical Mind - The Cognitive Psychology of Music. Oxford: Clarendon Press, 1985.

STEIN, M. Jung - O mapa da alma: uma introdução. São Paulo: Cultrix, 2006. 212 p. STUMPF, Carl. The Origins of Music. Oxford: OUP Oxford, 2012. 288p.

TAME, D. O poder oculto da música. Tradução de Octavio Mendes Cajado. 14ª . ed. São Paulo: Pensamento-Cultrix, 1984. 334 p. Título original: The secret power of music: The trasnsformation of Self and Society through musical energy.

TOMÁS, L. Ouvir o lógos: música e Filosofia. São Paulo: UNESP, 2002. 137 p.

Música e filosofia: estética musical. São Paulo: Irmãos Vitale, 2005. 96 p. Conexões Musicais.

TORÁ. A Lei de Moisés Torá. Tradução de Meir Matzliah Melamed. 1. ed. Rio de Janeiro: Editora e Livraria Sêfer, 1962. 685 p.

TORRANO, J. Hesíodo: Teogonia a origem dos Deuses. 3a ${ }^{a}$ ed. São Paulo: Iluminuras, 1995. 121 p. Título Original do poema: Theogonia. 
CARVALHO, A. C. de; RAMALHO, C. G. de A. Cosmogonias e a música: Reflexão acerca do inconsciente coletivo e as representações musicais nos mitos de origem. R. Cientifica UBM - Barra Mansa (RJ), ano XXIX, v. 21, n. 41, 2. Sem. 2019. p. 61-88.

ISSN 1516-4071

WALLIN, N.; MERKER B. \& BROWN S. The Origins of Music. Cambridge: MIT Press, 2001. p. 498

WISNIK, J. O Som e o sentido: uma outra história da música. 2a ${ }^{\text {a }}$ ed. São Paulo: Companhia das Letras, 1989. 283 p.

ZATORRE, R \& PERETZ, I. The Biological Foundations of Music. San Diego: Academic Press, 2001. p. 463. 